\title{
The use of aripiprazole in the treatment of mental disorders in children and adolescents
}

\section{Zastosowanie aripiprazolu w leczeniu zaburzeń psychicznych u dzieci i młodzieży}

\author{
1 Department of Psychiatry and Psychotherapy of Developmental Age, John Paul II Paediatric Centre, Sosnowiec, Poland \\ ${ }^{2}$ Department of Pharmacology, School of Medicine in Katowice, Medical University of Silesia, Katowice, Poland \\ ${ }^{3}$ Department of Psychiatry and Psychotherapy, Medical University of Silesia, Katowice, Poland \\ ${ }^{4}$ Department of Rehabilitation Psychiatry, Medical University of Silesia, Katowice, Poland \\ Correspondence: Lena Cichoń, Department of Psychiatry and Psychotherapy of Developmental Age, John Paul II Paediatric Centre, Sosnowiec, Gabrieli Zapolskiej 3, 41-218 Sosnowiec, Poland, \\ tel.: +4832720 7700 ext. 704, mobile phone: +48 535788 296, e-mail: lenacichon@interia.pl
}

\author{
1 Oddział Kliniczny Psychiatrii i Psychoterapii Wieku Rozwojowego, Centrum Pediatrii im. Jana Pawła Il w Sosnowcu Sp. z 0.0., Sosnowiec, Polska \\ 2 Zakład Farmakologii, Katedra Farmakologii, Wydział Lekarski w Katowicach, Śląski Uniwersytet Medyczny w Katowicach, Katowice, Polska \\ ${ }^{3}$ Katedra Psychiatrii i Psychoterapii, Śląski Uniwersytet Medyczny w Katowicach, Katowice, Polska \\ ${ }^{4}$ Klinika Rehabilitacji Psychiatrycznej, Wydział Lekarski w Katowicach, Śląski Uniwersytet Medyczny w Katowicach, Katowice, Polska \\ Adres do korespondencji: Lena Cichoń, Oddział Kliniczny Psychiatrii i Psychoterapii Wieku Rozwojowego, Centrum Pediatrii im. Jana Pawła Il w Sosnowcu Sp. z 0.0., \\ ul. Gabrieli Zapolskiej 3, 41-218 Sosnowiec, tel.: +4832720 7700 w. 704, tel. kom.: +48535 788 296, e-mail: lenacichon@interia.pl
}

Abstract The article is about aripiprazole - an atypical antipsychotic that is registered in Poland for the treatment of schizophrenia in individuals aged $\geq 15$ years, and moderate to severe manic episodes in the course of bipolar disorder type I in adolescents aged $\geq 13$ years in the treatment lasting up to 12 weeks. The paper discusses the mechanism of action, pharmacokinetics, and safety of aripiprazole in the paediatric population. Aripiprazole acts as a partial agonist of the dopamine $\mathrm{D}_{2}$ receptor and the serotonin $5 \mathrm{HT}_{1 \mathrm{~A}}$ receptor. Aripiprazole pharmacokinetics in humans is linear and proportional to the dose range of 5-30 mg. In children and adolescents aged 10-17 years, the pharmacokinetic profile is comparable to that observed in adults, after the adjustment for body weight. The article also contains a review of research on the clinical efficacy of aripiprazole in the treatment of psychiatric disorders, such as: schizophrenia, bipolar disorder, hyperkinetic disorder, pervasive developmental disorders, tics and aggressive behaviours in children and adolescents. Aripiprazole evaluated in clinical trials among children and adolescents has shown a good safety and tolerability profile. The incidence and type of side effects of aripiprazole in the paediatric population are essentially similar to those observed in adults. However, by contrast with adults, adolescents treated with aripiprazole may more often develop such side effects as drowsiness, sedation, extrapyramidal symptoms, dry mouth, increased appetite, and orthostatic hypotension. Aripiprazole may play an important role in the treatment of psychiatric disorders in children and adolescents because of its favourable metabolic profile.

Keywords: aripiprazole, children, pharmacology, atypical antipsychotic, pharmacokinetics

Streszczenie Artykuł dotyczy aripiprazolu - atypowego leku przeciwpsychotycznego, który w Polsce jest zarejestrowany w terapii schizofrenii u osób w wieku $\geq 15$ lat oraz epizodów maniakalnych o nasileniu umiarkowanym do ciężkiego w przebiegu zaburzenia afektywnego dwubiegunowego typu I u młodzieży w wieku $\geq 13$ lat w leczeniu trwającym do 12 tygodni. Omówiono mechanizm działania, farmakokinetykę oraz bezpieczeństwo stosowania aripiprazolu w populacji dzieci i młodzieży. Aripiprazol działa jako częściowy agonista receptora dopaminowego $\mathrm{D}_{2}$ i serotoninowego $5 \mathrm{HT}_{1 \mathrm{~A}}$. Farmakokinetyka aripiprazolu u ludzi jest liniowa i proporcjonalna do dawki w zakresie 5-30 mg. U dzieci i młodzieży w wieku 10-17 lat profil farmakokinetyczny leku jest porównywalny do obserwowanego u osób dorosłych, po korekcie różnic w masie ciała. Artykuł zawiera także przegląd badań dotyczących skuteczności klinicznej aripiprazolu w leczeniu zaburzeń psychiatrycznych, tj. schizofrenii, zaburzeń afektywnych dwubiegunowych, zaburzeń hiperkinetycznych, całościowych zaburzeń rozwojowych, tików oraz zachowań agresywnych u dzieci i młodzieży. W próbach klinicznych populacji pediatrycznej lek wykazuje dobry profil bezpieczeństwa i tolerancji. Częstość występowania i rodzaj działań niepożądanych aripiprazolu wśród dzieci i młodzieży są zasadniczo podobne jak w przypadku osób dorosłych. Jednak u młodzieży leczonej aripiprazolem mogą częściej niż u dorosłych pojawiać się efekty uboczne, takie jak senność, sedacja, objawy pozapiramidowe, suchość w jamie ustnej, wzrost apetytu i niedociśnienie ortostatyczne. Wydaje się, że aripiprazol z powodu swojego korzystniejszego profilu metabolicznego może odgrywać istotną rolę w leczeniu zaburzeń psychiatrycznych u dzieci i młodzieży. 


\section{INTRODUCTION}

A typical antipsychotics (which include aripiprazole) are the most common group of antipsychotics used in the treatment of psychosis in the paediatric population. Furthermore, their use in the treatment of other psychiatric disorders in children and adolescents, including off-label indications, is constantly increasing (Whitney et al., 2015). Antipsychotic drugs intended for this group of patients have to meet specific requirements relating to safety, tolerability, and effect on cognitive function due to the possibility of age-dependent changes in their pharmacodynamics and pharmacokinetics. A reaction to antipsychotic drugs during the developmental period may in fact significantly differ from that observed in adults due to slow maturation of the brain noradrenergic system and greater saturation with dopaminergic receptors $D_{1}$ and $D_{2}$. Young persons may also be more sensitive to the occurrence of extrapyramidal symptoms (EPS) and body weight gain associated with antipsychotic therapy. The rationale for the use of more selective new generation neuroleptics in children and adolescents is therefore the existence of significant differences in the pharmacokinetics in the developmental age, i.e. faster absorption, increased permeability of the blood-brain barrier, faster metabolism, decreased efficiency related to the effect of sex hormones on the binding of drugs to plasma proteins, or the reduction of excretion by kidneys.

In Poland, aripiprazole is registered for the treatment of schizophrenia in adults aged $\geq 15$ years, and moderate to severe manic episodes in the course of bipolar disorder (BD) type I in adolescents aged $\geq 13$ years in the treatment lasting up to 12 weeks (Summary of product characteristics - aripiprazole). The drug is reimbursed by the Polish National Health Fund for both indications. On the other hand, the Food and Drug Administration (FDA) recommends oral aripiprazole for the treatment of severe depressive disorder in adults, schizophrenia in persons aged $>13$ years, $\mathrm{BD}$ (manic and mixed episodes) in persons aged $>10$ years, as well as for Gilles Tourette's syndrome (GTS) and irritability in children with autism spectrum disorder (ASD) aged $>6$ years. There is a need for an objective review of the clinical use and safety profile of aripiprazole in patients in developmental age. The article discusses pharmacodynamic and pharmacokinetic properties of the drug, and outlines studies on its efficacy and tolerability in the paediatric population.

\section{MECHANISM OF ACTION}

Aripiprazole is, by some authors, called a third generation antipsychotic drug to distinguish it from other atypical neuroleptics (second generation antipsychotic drugs) (Mailman and Murthy, 2010). In contrast to other atypical neuroleptics exhibiting a different level of antagonism

\section{WPROWADZENIE}

$\mathrm{N}$ euroleptyki atypowe (do których zalicza się aripiprazol) są najczęściej stosowaną grupą leków przeciwpsychotycznych w terapii psychoz wśród populacji dziecięcej. Ponadto ciągle wzrasta ich zastosowanie $\mathrm{w}$ leczeniu innych zaburzeń psychicznych $\mathrm{u}$ dzieci i młodzieży, także pozarejestracyjne (Whitney et al., 2015). Leki antypsychotyczne stosowane w tej grupie chorych muszą spełniać szczególne wymogi dotyczące ich bezpieczeństwa, tolerancji oraz wpływu na funkcje poznawcze - istnieje bowiem możliwość wystąpienia zależnych od wieku zmian w ich farmakodynamice i farmakokinetyce. Reakcja na leki przeciwpsychotyczne w okresie rozwojowym może istotnie różnić się od tej obserwowanej u osób dorosłych - ze względu na wolniejsze dojrzewanie układu noradrenergicznego mózgu oraz większe nasycenie receptorami dopaminergicznymi $\mathrm{D}_{1}$ i $\mathrm{D}_{2}$. Osoby młode mogą także być bardziej wrażliwe na wystąpienie objawów pozapiramidowych (OPP) i wzrostu wagi ciała, związanych z terapią lekami przeciwpsychotycznymi. Uzasadnieniem do stosowania u dzieci i młodzieży bardziej selektywnych neuroleptyków nowej generacji są zatem istotne odmienności farmakokinetyki wieku rozwojowego, tj. szybsza absorpcja, większa przepuszczalność bariery krew-mózg, szybszy metabolizm, osłabienie efektywności w wyniku wpływu hormonów płciowych na wiązanie leków z białkami osocza czy zmniejszenie wydalania przez nerki. W Polsce aripiprazol jest zarejestrowany $\mathrm{w}$ terapii schizofrenii u osób $\mathrm{w}$ wieku $\geq 15$ lat oraz epizodów maniakalnych o nasileniu umiarkowanym do ciężkiego w przebiegu zaburzenia afektywnego dwubiegunowego (bipolar disorder, $\mathrm{BD}$ ) typu I u młodzieży w wieku $\geq 13$ lat w leczeniu trwającym do 12 tygodni (Summary of product characteristics - aripiprazole). Lek podlega refundacji przez Narodowy Fundusz Zdrowia w obu wskazaniach. Z kolei amerykańska Agencja Żywności i Leków (Food and Drug Administration, FDA) rekomenduje stosowanie aripiprazolu $\mathrm{w}$ formie doustnej w leczeniu wspomagającym ciężkich zaburzeń depresyjnych u osób dorosłych, schizofrenii u osób powyżej 13. roku życia oraz BD - epizodów maniakalnych lub mieszanych - u osób powyżej 10. roku życia, a także w leczeniu zespołu Tourettea (Gilles Tourette’s syndrome, GTS) i drażliwości u dzieci z zaburzeniami ze spektrum autyzmu (autism spectrum disorder, ASD) powyżej 6. roku życia. Istnieje więc potrzeba dokonania obiektywnego przeglądu zastosowania klinicznego i profilu bezpieczeństwa aripiprazolu u pacjentów w wieku rozwojowym. W artykule omówiono właściwości farmakodynamiczne i farmakokinetyczne leku oraz badania dotyczące jego skuteczności i tolerancji w populacji pediatrycznej.

\section{MECHANIZM DZIAŁANIA}

Aripiprazol jest przez niektórych autorów określany mianem leku przeciwpsychotycznego trzeciej generacji - w celu odróżnienia go od innych neuroleptyków atypowych (leków antypsychotycznych generacji drugiej) (Mailman i Murthy, 2010). 
dopamine $\mathrm{D}_{2}$ receptor and the serotonin $5 \mathrm{HT}_{1 \mathrm{~A}}$ receptor. Drugs called "partial agonists" have a lower intrinsic activity than endogenous "full agonists." Depending on the environment, partial agonists can induce different receptor responses: (a) in the absence of a full agonist, they behave like agonists but produce a weaker response of the receptor, or (b) at high concentrations of full agonists, they act as antagonists (Bolonna and Kerwin, 2005). This means that aripiprazole may modulate the degree of $\mathrm{D}_{2}$-receptor blockade, which is the most important for the induction of the antipsychotic effect (especially against hallucinations and delusions) (Gardner et al., 2005). Aripiprazole acts as an antagonist of $\mathrm{D}_{2}$ receptors in the areas of an increased dopaminergic transmission, and as $\mathrm{a}_{2}$ agonist in the areas where the transmission is decreased, which leads to its normalisation (Hirose and Kikuchi, 2005). A total blockade of dopaminergic receptors is therefore not observed after the use of aripiprazole. Partial agonism of aripiprazole has been demonstrated both against the postsynaptic $\mathrm{D}_{2}$ receptors and presynaptic $\mathrm{D}_{2}$ autoreceptors (Gardner et al., 2005). A confirmation of this effect of aripiprazole on $\mathrm{D}_{2}$ receptors can be found in the results of tests performed with the use of positron emission tomography (PET), wherein healthy subjects were administered the drug at a dose of $0.5-30 \mathrm{mg}$ once a day for 2 weeks and demonstrated a dosage-dependent reduction in binding of [11C]-raclopride, a ligand of a $\mathrm{D}_{2} / \mathrm{D}_{3}$ receptor, in the caudate and putamen (Yokoi et al., 2002). The result of the partial agonism on postsynaptic $\mathrm{D}_{2}$ receptors is a reduced tendency to their up-regulation and a lower probability to cause EPS. In contrast, partial agonism of aripiprazole towards $5 \mathrm{HT}_{1 \mathrm{~A}}$ receptors is related to the anxiolytic effect and to the reduction of the risk of the EPS development (DeLeon et al., 2004). Like other atypical neuroleptics, aripiprazole is also a $5 \mathrm{HT}_{2 \mathrm{~A}}$ receptor antagonist, which has a beneficial effect on negative and affective symptoms, cognitive deficits and reduction of EPS severity. Aripiprazole also has a strong affinity for dopamine $\mathrm{D}_{3}$ receptors, moderate affinity to $\mathrm{D}_{4}, 5 \mathrm{HT}_{2 \mathrm{C}}, 5 \mathrm{HT}_{7}$, al-adrenergic, $\mathrm{H}_{1}$-histaminic receptors and to the serotonin transporter. It has, however, no appreciable affinity for cholinergic muscarinic receptors (Bolonna and Kerwin, 2005). The effect on receptors other than $\mathrm{D}_{2}, 5 \mathrm{HT}_{1 \mathrm{~A}}$ and $5 \mathrm{HT}_{2 \mathrm{~A}}$ explains the occurrence of some of the side effects of aripiprazole (e.g. its antagonism to $\alpha_{1}$-adrenergic receptors can cause hypotension) (Greenaway and Elbe, 2009).

\section{PHARMACOKINETIC PROFILE}

Aripiprazole pharmacokinetics in humans is linear and proportional to the dose range of 5-30 $\mathrm{mg}$ (DeLeon et al., 2004). In children and adolescents aged 10-17 years, the pharmacokinetic profile is comparable to that observed in adults, after the adjustment for body weight.

Aripiprazole is well-absorbed from the gastrointestinal tract. Maximum plasma concentrations are attained
Inaczej bowiem niż inne neuroleptyki atypowe, wykazujące różny poziom antagonizmu wobec receptorów $\mathrm{D}_{2}$, aripiprazol działa jako częściowy agonista receptora dopaminowego $\mathrm{D}_{2}$ i serotoninowego $5 \mathrm{HT}_{1 \mathrm{~A}}$. Leki nazywane częściowymi agonistami odznaczają się niższą aktywnością wewnętrzną niż endogenni pełni agoniści. W zależności od środowiska częściowi agoniści mogą wywoływać różną odpowiedź receptorową: (a) w przypadku braku obecności pełnego agonisty zachowują się jak agoniści, ale wywołują słabszą odpowiedź ze strony receptora lub (b) przy wyższych stężeniach pełnego agonisty działają jak antagoniści (Bolonna i Kerwin, 2005). Oznacza to, iż aripiprazol może modulować stopień blokady receptorów $\mathrm{D}_{2}$ - najistotniejszej dla wywołania efektu antypsychotycznego (zwłaszcza przeciw omamom i urojeniom) (Gardner et al., 2005). Lek ten działa jako antagonista receptorów $\mathrm{D}_{2} \mathrm{w}$ obszarach o nasilonej transmisji dopaminergicznej, a jako agonista $\mathrm{D}_{2}-\mathrm{w}$ obszarach o jej osłabieniu, co zmierza do normalizacji (Hirose i Kikuchi, 2005). Dlatego też po aripiprazolu nie obserwuje się całkowitej blokady receptorów dopaminergicznych. Częściowy agonizm leku wykazano zarówno wobec postsynaptycznych receptorów $\mathrm{D}_{2}$, jak i presynaptycznych autoreceptorów $\mathrm{D}_{2}$ (Gardner et al., 2005). Potwierdzeniem takiego wpływu aripiprazolu na receptory $\mathrm{D}_{2}$ są wyniki badania przy użyciu pozytronowej tomografii emisyjnej (positron emission tomography, PET), w którym po podaniu w dawkach 0,5-30 mg leku raz na dobę przez 2 tygodnie osobom zdrowym wykazano dawkozależne zmniejszenie wiązania $\left[{ }^{11} \mathrm{C}\right]$-rakloprydu - liganda receptora $\mathrm{D}_{2} / \mathrm{D}_{3}-\mathrm{w}$ jądrze ogoniastym i skorupie (Yokoi et al., 2002). Skutkami częściowego agonizmu wobec postsynaptycznych $\mathrm{D}_{2}$ są zmniejszona tendencja do ich „up-regulacji” i mniejsze ryzyko wywołania OPP. Natomiast częściowy agonizm aripiprazolu wobec receptorów $5 \mathrm{HT}_{1 \mathrm{~A}}$ ma związek $\mathrm{z}$ jego efektem przeciwlękowym i redukcją ryzyka OPP (DeLeon et al., 2004). Podobnie jak inne neuroleptyki atypowe, lek ten jest także antagonistą receptorów $5 \mathrm{HT}_{2 \mathrm{~A}}$, przez co korzystnie wpływa na objawy negatywne i afektywne oraz na zaburzenia funkcji poznawczych, a także zmniejsza nasilenie OPP. Aripiprazol wykazuje również silne powinowactwo do receptorów dopaminowych $\mathrm{D}_{3}$ oraz umiarkowane - do $\mathrm{D}_{4}, 5 \mathrm{HT}_{2 \mathrm{C}}$, $5 \mathrm{HT}_{7}$, adrenergicznych $\alpha_{1}$, histaminowych $\mathrm{H}_{1}$ i transportera wychwytu zwrotnego serotoniny. Nie ma natomiast istotnego powinowactwa do cholinergicznych receptorów muskarynowych (Bolonna i Kerwin, 2005). Wpływ na receptory inne niż $\mathrm{D}_{2}, 5 \mathrm{HT}_{1 \mathrm{~A}}$ i $5 \mathrm{HT}_{2 \mathrm{~A}}$ pozwala na wyjaśnienie niektórych efektów ubocznych aripiprazolu (np. antagonizm leku wobec receptorów adrenergicznych $\alpha_{1}$ może być przyczyną hipotensji) (Greenaway i Elbe, 2009).

\section{PROFIL FARMAKOKINETYCZNY}

Farmakokinetyka aripiprazolu u ludzi jest liniowa i proporcjonalna do dawki w zakresie 5-30 mg (DeLeon et al., 2004). U dzieci i młodzieży w wieku 10-17 lat profil farmakokinetyczny leku jest porównywalny do obserwowanego u osób dorosłych, po korekcie różnic w masie ciała. 
within 3-5 hours after administration and become steady after 14 days of use. The bioavailability is $87 \%$ (DeLeon et al., 2004). The drug has a high volume of distribution $(4.9 \mathrm{~L} / \mathrm{kg})$, and its binding to blood albumins is high (>99\%). Aripiprazole is primarily metabolised in the liver by dehydrogenation in the presence of CYP450 isoenzymes (CYP3A4 and CYP2D6). As a result an active metabolite, dehydroaripiprazole, is produced, which accounts for about $40 \%$ of the drug concentration in the steady state. Although dehydroaripiprazole exhibits a similar affinity for $\mathrm{D}_{2}$ receptors as aripiprazole, its involvement in the clinical effect of the original compound has not yet been determined. The drug is eliminated mainly by metabolic clearance. In humans, metabolites of aripiprazole are eliminated via the kidneys and in bile. Following a single oral dose of $\left[{ }^{14} \mathrm{C}\right]$ aripiprazole, $25 \%$ and $37 \%$ of the radioactivity of the drug in the form of metabolites was found in urine and faeces, respectively. Less than $1 \%$ of unchanged aripiprazole was excreted in urine and approximately $18 \%$ of it in faeces. The half-life in the terminal phase of elimination after intravenous administration of aripiprazole is 99 hours. Because of the polymorphism of the CYP450 enzyme, the half-life of aripiprazole elimination can be increased up to approximately 150 hours in poor metabolizers, who represent approximately $8 \%$ of Caucasians subjects (Greenaway and Elbe, 2009). Gender and liver or renal failure affect the pharmacokinetic parameters of the drug (Sheehan et al., 2010).

\section{CLINICAL EFFICACY OF ARIPIPRAZOLE IN CHILDREN AND ADOLESCENTS}

\section{Schizophrenia}

Schizophrenia is a disorder occurring in $\sim 1 \%$ of the adult population. Clinical symptoms of schizophrenia appear most frequently in the second or third decade of life. The beginning of schizophrenia before the age of 15 occurs in $4 \%$ of patients and before the age of 10 in only $1 \%$ of patients (Asarnow and Forsyth, 2013). The disease is characterised by positive symptoms (hallucinations, delusions) and negative symptoms (deficit symptoms limiting mental activities). The aetiology of schizophrenia is multifactorial and is not fully understood. In its pathogenesis, the involvement of the following factors is suggested: disturbance of the monoaminergic (especially dopaminergic) neurotransmission systems, genetic and environmental factors, disorders of brain cytoarchitecture system and of brain metabolism of neuropeptides (cholecystokinin, neurotensin) as well as immunological changes.

The clinical picture of schizophrenia in children and adolescents may differ from that observed in adults. Therefore, the diagnosis of schizophrenia in the initial stage in the paediatric population can be very difficult. In a significant percentage of people with childhood-on-
Aripiprazol dobrze się wchłania z przewodu pokarmowego. Maksymalne stężenie w osoczu osiąga w ciągu 3-5 godzin od podania, a stężenie stacjonarne - po 14 dniach stosowania. Biodostępność wynosi 87\% (DeLeon et al., 2004). Lek ma wysoką objętość dystrybucji $(4,9$ l/kg) i jest wysoce wiązany $\mathrm{z}$ albuminami krwi (>99\%). Aripiprazol jest głównie metabolizowany w wątrobie, na drodze dehydrogenacji przy udziale izoenzymów CYP450 (CYP3A4 i CYP2D6) i wytworzenia aktywnego metabolitu - dehydroaripiprazolu, który stanowi około $40 \%$ leku w stanie stacjonarnym. Mimo iż dehydroaripiprazol wykazuje podobne powinowactwo do receptorów $\mathrm{D}_{2}$ jak w przypadku aripiprazolu, to jednak jego udział w efekcie klinicznym związku macierzystego nie został do tej pory określony. Lek jest eliminowany przede wszystkim przez klirens metaboliczny. U ludzi metabolity aripiprazolu są usuwane zarówno przez nerki, jak i z żółcią. Po doustnym podaniu pojedynczej dawki aripiprazolu znakowanego $\left[{ }^{14} \mathrm{C}\right]$ stwierdzono $25 \%$ i $37 \%$ radioaktywności leku w postaci metabolitów - odpowiednio w moczu i kale. Mniej niż 1\% leku w postaci niezmienionej zostaje wydalone $\mathrm{z}$ moczem, a około $18 \%$ - z kałem. Okres półtrwania w końcowej fazie eliminacji po podaniu dożylnym aripiprazolu wynosi 99 godzin. $Z$ powodu polimorfizmu enzymów CYP450 okres półtrwania aripiprazolu w fazie eliminacji może ulec wydłużeniu do około 150 godzin u słabych metabolizerów, stanowiących około 8\% rasy kaukaskiej (Greenaway i Elbe, 2009). Płeć oraz niewydolność wątroby lub nerek wpływają na parametry farmakokinetyczne leku (Sheehan et al., 2010).

\section{SKUTECZNOŚĆ KLINICZNA ARIPIPRAZOLU W POPULACJI DZIECI I MŁODZIEŻY}

\section{Schizofrenia}

Schizofrenia jest zaburzeniem występującym $\mathrm{u} \sim 1 \%$ populacji osób dorosłych. Objawy kliniczne tej choroby pojawiają się najczęściej w 2. lub 3. dekadzie życia. Jej początek przed 15. rokiem życia występuje u $4 \%$ chorych, a tylko u $1 \%$ przed 10. rokiem życia (Asarnow i Forsyth, 2013). Choroba charakteryzuje się występowaniem objawów pozytywnych (halucynacje, urojenia) i negatywnych (deficytowych, polegających na ograniczeniu czynności psychicznych). Etiologia schizofrenii jest wieloczynnikowa i nie do końca wyjaśniona. W patogenezie choroby sugeruje się udział m.in.: zaburzeń neuroprzekaźnictwa w układach monoaminergicznych (zwłaszcza dopaminergicznym), czynników genetycznych i środowiskowych, zaburzeń cytoarchitektury mózgu, zaburzeń metabolizmu neuropeptydów (cholecystokininy, neurotensyny) czy też zmian immunologicznych.

Obraz kliniczny schizofrenii u dzieci i młodzieży może się różnić od przebiegu choroby u osób dorosłych. Dlatego jej rozpoznanie w początkowym stadium wśród populacji pediatrycznej bywa bardzo trudne. Znaczny odsetek osób ze schizofrenią mającą początek w dzieciństwie prezentuje jeszcze przed wystąpieniem choroby zaburzenia funkcji językowych, motorycznych, problemy w sferze społecznej, 
motor skills, problems in the social sphere, learning difficulties, and mood and anxiety disorders before the onset of the disease (Driver et al., 2013). Psychotic symptoms in the developmental age can occur not only in schizophrenia, but also in the course of other psychotic disorders (e.g. affective disorders), somatic diseases (e.g. hypothyroidism), or as a result of the use of psychoactive substances (Algon et al., 2012).

In the treatment of schizophrenia in adolescents $\geq 15$ years of age and older, the recommended dose of aripiprazole is $10 \mathrm{mg}$ once daily, regardless of meals. The treatment should start with a dose of $2 \mathrm{mg}$ for 2 days, titrated to $5 \mathrm{mg}$ for 2 days to reach the recommended daily dose of $10 \mathrm{mg}$. In cases requiring higher doses of aripiprazole (>10 mg), the subsequent doses should be increased by $5 \mathrm{mg}$ at a time, not exceeding the maximum daily dose of $30 \mathrm{mg}$ (Summary of product characteristics - aripiprazole). The efficacy of aripiprazole in the treatment of schizophrenia in adolescents has been evaluated in a 6-week multicentre, randomised, double-blind, placebo-controlled study, in which the researchers recruited $302 \mathrm{pa}-$ tients aged 13-17 years with the disease diagnosed according to DSM-IV (Diagnostic and Statistical Manual of Mental Disorders) criteria and with the result in the total Positive and Negative Syndrome Scale (PANSS) $\geq 70$. The patients were randomised to three groups in a ratio of $1: 1: 1$, receiving: placebo, 10 or $30 \mathrm{mg}$ of aripiprazole daily. Aripiprazole was initiated at a starting dose of $2 \mathrm{mg} /$ day, and the dose was gradually increased every 2 days up to the target levels, which were then continued for at least 2 weeks. Eighty-five per cent of the patients completed the study. The effectiveness of the treatment was measured with the use the PANSS subscales: PANSS-P evaluating positive symptoms (delusions, hallucinations, agitation, grandiosity, suspiciousness/persecution), PANSS-N estimating negative symptoms (blunted affect, apathy, anhedonia, poverty of thought and content of speech, perseverance in the performance of complex tasks), Clinical Global Impression - Severity scale (CGI-S), Clinical Global Impression - Improvement scale (CGI-I), and Children's Global Assessment Scale (CGAS). The study revealed significantly greater clinical efficacy of both doses of aripiprazole in relieving the symptoms of schizophrenia compared to placebo, which was reflected by a significant improvement in total PANSS, PANSS-P subscale and CGI-S, CGI-I and CGAS scales. In the group treated with $10 \mathrm{mg}$ of aripiprazole, an improvement in PANSS-N subscales compared to placebo was also observed. However, in patients receiving $30 \mathrm{mg}$ of aripiprazole per day, an improvement in PANSS-N subscales was observed in the $3^{\text {rd }}$ and $4^{\text {th }}$ week of treatment, but this effect was not maintained until the end of the study. In the groups treated with both doses of the drug, remission rates in the $6^{\text {th }}$ week of the study were also significantly higher than in the placebo group (Findling et al., 2008a). trudności w nauce, a także zaburzenia nastroju czy lękowe (Driver et al., 2013). Objawy psychotyczne w okresie rozwojowym mogą wystąpić nie tylko w przypadku schizofrenii, lecz także w przebiegu innych chorób psychicznych (np. zaburzeń afektywnych), chorób somatycznych (np. niedoczynności tarczycy) lub na skutek używania substancji psychoaktywnych (Algon et al., 2012).

W leczeniu schizofrenii u młodzieży w wieku $\geq 15$ lat i starszej zalecana dawka aripiprazolu wynosi $10 \mathrm{mg} /$ dobę jednorazowo, niezależnie od posiłków. Leczenie należy rozpocząć od dawki $2 \mathrm{mg}$ przez 2 dni, stopniowo zwiększać do $5 \mathrm{mg}$ przez kolejne $2 \mathrm{dni}$, aż do osiągnięcia zalecanej dawki dobowej $10 \mathrm{mg}$. W przypadkach wymagających większych dawek aripiprazolu (>10 mg) kolejne dawki należy zwiększać jednorazowo o $5 \mathrm{mg}$, nie przekraczając maksymalnej dawki dobowej w wysokości $30 \mathrm{mg}$ (Summary of product characteristics - aripiprazole).

Skuteczność aripiprazolu w leczeniu schizofrenii u młodzieży oceniono w 6-tygodniowym wieloośrodkowym, randomizowanym badaniu z podwójnie ślepą próbą i kontrolą placebo. Wzięło w nim udział 302 pacjentów w wieku 13-17 lat $\mathrm{z}$ chorobą zdiagnozowaną według kryteriów klasyfikacji zaburzeń psychicznych Amerykańskiego Towarzystwa Psychiatrycznego (Diagnostic and Statistical Manual of Mental Disorders, DSM-IV) oraz wynikiem w całkowitej skali objawów pozytywnych i negatywnych schizofrenii (Positive and Negative Syndrome Scale, PANSS) $\geq 70$. Pacjenci byli dobierani losowo do trzech grup, które w stosunku 1:1:1 otrzymywały: placebo, 10 lub $30 \mathrm{mg} /$ dobę aripiprazolu. Leczenie aripiprazolem rozpoczynano od dawki początkowej w wysokości $2 \mathrm{mg} /$ dobę i stopniowo zwiększano ją co 2 dni do dawek docelowych, które stosowano przynajmniej przez 2 tygodnie. Badanie ukończyło 85\% pacjentów. Efektywność terapii mierzono przy użyciu: PANSS, podskali oceniającej objawy pozytywne (PANSS-P; obejmują one urojenia, halucynacje, pobudzenie, wielkościowość, podejrzliwość/prześladowanie), podskali szacującej objawy negatywne (PANSS-N; należą do nich stępienie afektu, apatia, anhedonia, zubożenie myślenia i treści wypowiedzi, wytrwałość w wykonywaniu złożonych czynności), skali ogólnego wrażenia klinicznego dotyczącego nasilenia objawów (Clinical Global Impression - Severity scale, CGI-S), skali ogólnego wrażenia klinicznego dotyczącego uzyskanej poprawy (Clinical Global Impression Improvement scale, CGI-I) oraz skali globalnej oceny dziecka przez specjalistów (Children's Global Assessment Scale, CGAS). Stwierdzono istotnie większą skuteczność kliniczną terapii obydwoma dawkami aripiprazolu w łagodzeniu objawów schizofrenii w porównaniu $z$ placebo, co wykazano poprzez istotną poprawę w PANSS, PANSS-P oraz CGI-S, CGI-I i CGAS. W grupie leczonej $10 \mathrm{mg}$ aripiprazolu zaobserwowano również poprawę w PANSS-N w porównaniu z placebo. Natomiast u pacjentów otrzymujących $30 \mathrm{mg}$ aripiprazolu na dobę poprawę w PANSS-N obserwowano w 3. i 4. tygodniu leczenia, ale efekt ten nie utrzymał się do końca badania. Wśród osób leczonych obydwiema dawkami leku stwierdzono także znacznie wyższe wskaźniki remisji w 6 . tygodniu badania niż w grupie placebo (Findling et al., 2008a). 


\section{Prodromal phase of psychosis}

Woods et al. (2007) in the single-centre open-label study evaluated the effectiveness of aripiprazole in 15 young people $(17.1 \pm 5.5$ years $)$ with prodromal symptoms of psychosis. The patients received aripiprazole in doses of 5-30 mg/day for 8 weeks. The effectiveness of the therapy was measured with the Scale of Prodromal Symptoms (SOPS). A significant improvement in the overall SOPS score was recorded in the first week of treatment. Thirteen patients completed the study, and none of them developed psychosis. The disadvantage of the study was, however, a small number of participants and the absence of a placebo control group.

\section{Manic episodes in the course of BD}

$\mathrm{BD}$ is a chronic condition characterised by depressive, manic/hypomanic or mixed episodes, with an increase in prevalence in the paediatric population observed in recent years (Leibenluft, 2011). According to a meta-analysis published in 2011, the incidence of paediatric bipolar disorder (PBD) in children and adolescents is estimated at 1.8\% (Van Meter et al., 2011). Because of the differences in clinical presentation of PBD (e.g. higher incidence of mixed states in children, fewer psychotic symptoms, shorter episodes of mania, rapid cycling) compared to BD which occurs in adulthood, many young patients may be initially incorrectly diagnosed. Making a proper diagnosis in children and adolescents is complicated by a comorbidity and overlap of symptoms of attention deficit hyperactivity disorder (ADHD), oppositional defiant disorder, conduct disorder, depression or anxiety disorders (Renk et al., 2014). In the study by Perlis et al. (2004) involving 983 adult patients with BD, it was found, that in the first episode of the disease occurred before the $13^{\text {th }}$ year of age in $27.7 \%$ of the participants, and between the $13^{\text {th }}$ and $18^{\text {th }}$ year of age in $37.6 \%$ of them. Early age of onset appears to be associated with worse prognosis and course of BD (Perlis et al., 2004). Patients have difficulty in functioning in the family, at school and later at work. They are also at areater risk of substance use, suicidal thoughts and suicidal attempts (Axelson et al., 2006; Esposito-Smythers et al., 2006; Lewinsohn et al., 2000).

Aripiprazole is indicated for the treatment of moderate to severe manic episodes in the course of BD type I in adolescents aged 13 years and older. The recommended daily dose is $10 \mathrm{mg}$. Treatment duration should be as short as possible and should not exceed 12 weeks (Summary of product characteristics - aripiprazole).

Two large clinical trials evaluating the efficacy of aripiprazole in children and adolescents with $\mathrm{BD}$ were conducted by Findling et al. (2009b, 2011). The first 4-week, multicentre, randomised, double-blind study included 296 patients (aged 10-17) with acute manic or mixed episode in the course of PBD type I with/without psychotic

\section{Faza prodromalna psychozy}

Woods i wsp. (2007) w jednoośrodkowym badaniu otwartym ocenili skuteczność aripiprazolu u 15 młodych osób $(17,1 \pm 5,5$ roku $) \mathrm{z}$ objawami zwiastunowymi psychozy. Pacjenci otrzymywali lek w dawkach 5-30 mg/dobę przez 8 tygodni. Efektywność terapii szacowano na podstawie skali objawów prodromalnych psychozy (Scale of Prodromal Symptoms, SOPS). Istotną poprawę w całkowitej SOPS odnotowano w 1. tygodniu leczenia. Badanie ukończyło 13 osób, a u żadnej z nich nie rozwinęła się psychoza. Wadami badania były jednak mała liczba uczestników i brak grupy kontrolnej placebo.

\section{Epizody maniakalne w przebiegu BD}

BD jest przewlekłym zaburzeniem nastroju charakteryzującym się występowaniem epizodów depresji, manii/hipomanii lub mieszanych, którego częstość występowania w populacji dziecięcej wzrasta w ostatnich latach (Leibenluft, 2011). Zgodnie z wynikami metaanalizy opublikowanymi w 2011 roku zapadalność na BD w populacji pediatrycznej (paediatric bipolar disorder, PBD) ocenia się na 1,8\% (Van Meter et al., 2011). Z powodu odmienności manifestacji klinicznej PBD (np. częstsze występowanie u dzieci stanów mieszanych, szybka zmiana faz) w porównaniu z BD, która pojawia się w okresie dorosłości, wiele osób młodych może początkowo zostać niewłaściwie zdiagnozowanych.

Właściwe rozpoznanie u dzieci i młodzieży utrudniają współwystępowanie oraz nakładanie się objawów zespołu nadpobudliwości psychoruchowej z deficytem uwagi (attention deficit hyperactivity disorder, ADHD), zaburzeń opozycyjno-buntowniczych, zaburzeń zachowania, depresji czy zaburzeń lękowych (Renk et al., 2014). W badaniu Perlisa i wsp. (2004) obejmującym 983 dorosłych pacjentów z BD stwierdzono, że u 27,7\% pierwszy epizod choroby wystąpił przed 13. rokiem życia, a u 37,6\% - między 13. a 18. rokiem życia. Wczesny wiek zachorowania wydaje się mieć związek z gorszym rokowaniem i przebiegiem BD (Perlis et al., 2004). Pacjenci wykazują trudności w funkcjonowaniu rodzinnym, szkolnym i w późniejszej pracy. Istnieje u nich także większe ryzyko używania substancji psychoaktywnych, występowania myśli samobójczych i podejmowania prób suicydalnych (Axelson et al., 2006; Esposito-Smythers et al., 2006; Lewinsohn et al., 2000).

Aripiprazol jest wskazany w leczeniu epizodów maniakalnych o nasileniu umiarkowanym do ciężkiego w przebiegu BD typu I u młodzieży w wieku 13 lat i starszej. Zalecana dobowa dawka wynosi $10 \mathrm{mg}$. Czas trwania terapii powinien być możliwie jak najkrótszy i nie powinien przekraczać 12 tygodni (Summary of product characteristics - aripiprazole). Dwie duże próby kliniczne oceniające skuteczność aripiprazolu wśród dzieci i młodzieży z BD przeprowadzili Findling i wsp. (2009b, 2011). Pierwsze - 4-tygodniowe wieloośrodkowe, randomizowane, podwójnie zaślepione badanie objęło 296 osób (10-17 lat) z ostrym epizodem manii lub 
with BD type I according to DSM-IV (in a manic or mixed episode) and had the score of the Young Mania Rating Scale (YMRS) $\geq 20$. The participants were randomly assigned to three groups, in which they received: placebo, aripiprazole 10 or $30 \mathrm{mg}$ daily. Therapy effectiveness was measured as a change in the YMRS result compared to the baseline score. It was shown that both groups receiving aripiprazole had better YMRS scores than the placebo group between the $1^{\text {st }}$ and $4^{\text {th }}$ week of the study. The response at week 4 of treatment (reduction in YMRS total score of $\geq 50 \%$ ) was obtained in $44.8 \%$ of patients receiving $10 \mathrm{mg}$ and in $63.6 \%$ of patients receiving $30 \mathrm{mg}$ of aripiprazole, compared to $26.1 \%$ of patients in the placebo group (Findling et al., 2009b). The second study, which was an open label study, was conducted by Findling et al. (2011) among BD children with manic symptoms. The investigation involved 96 children aged from 4 to 9 years with a diagnosis of BD according to DSM-IV and with a score in YMRS $\geq 15$. The aripiprazole dose was modified depending on the patient's response (maximum dose $15 \mathrm{mg} /$ day). The effects of treatment were estimated using the following scales: YMRS, CGI-S, CGAS and Children's Depression Rating Scale-Revised (CDRS-R). The primary efficacy endpoint consisted of 3 out of 4 consecutive weeks with the following results: CDRS-R $<29$, YMRS $<10$, and CGAS $>50$. The drug was administered up to 16 weeks or until the criteria of the primary endpoint were met. The average duration of treatment with aripiprazole was 12.5 weeks. Sixty-two per cent of the children met the primary efficacy endpoint. At the end of the study, a significant increase in YMRS, CDRS-R, CGAS, and CGI-S was revealed. Thirtyeight per cent of patients showed no response to treatment with aripiprazole (Findling et al., 2011).

In turn, Biederman et al. (2007) conducted an 8-week, open, prospective study of the effectiveness of aripiprazole monotherapy in young people with $\mathrm{BD}(n=19)$. The effectiveness of treatment was evaluated using the YMRS, CGI-I, and Brief Psychiatric Rating Scale (BPRS). Fifteen patients completed the study and demonstrated significant clinical improvement, defined as a reduction in YMRS by $30 \%$, being a result of treatment with aripiprazole $(9.4 \pm 4.2 \mathrm{mg} / \mathrm{day})$. In another study, young people (aged 8-17 years) with a manic or mixed episode in the course of $\mathrm{BD}$ and comorbid $\mathrm{ADHD}$ received aripiprazole $(n=18)$ or placebo $(n=25)$ for 6 weeks. The primary assessment tools were the following scales: YMRS, Swanson, Nolan and Pelham Teacher and Parent Rating Scale (SNAP-IV), which were used to assess ADHD symptoms, and the secondary tools were CGI-S, Child Mania Rating Scale-Parent Version (CMRS-P), CDRS-R and Kutcher Adolescent Depression Scale (KADS). In the group treated with aripiprazole, a greater reduction in YMRS, CMRS-P and CGI-S as compared to placebo was demonstrated. No differences were observed between the groups in terms of remission of depression and ADHD (Tramontina et al., 2009). Tab. 1 summarises the available mieszanym w przebiegu PBD typu I z objawami psychotycznymi lub bez nich. Do badań włączono chorych z diagnozą BD typu I według DSM-IV - z epizodem manii lub mieszanym - oraz wynikiem w skali manii według Younga (Young Mania Rating Scale, YMRS) $\geq 20$. Pacjenci byli losowo przydzielani do trzech grup, które otrzymywały: placebo, 10 lub $30 \mathrm{mg}$ aripiprazolu na dobę. Miarą efektywności terapii była zmiana w wyniku YMRS w stosunku do stanu początkowego. Wykazano, że obie grupy przyjmujące aripiprazol miały korzystniejsze wyniki w YMRS niż grupa przyjmująca placebo, począwszy od 1. do 4. tygodnia badania. W 4. tygodniu leczenia odpowiedź (redukcja w skali YMRS o $\geq 50 \%$ ) uzyskano u 44,8\% osób otrzymujących $10 \mathrm{mg}$ i u $63,6 \%$ przyjmujących $30 \mathrm{mg}$ aripiprazolu - wobec $26,1 \%$ w grupie placebo (Findling et al., 2009b). Drugie badanie o charakterze otwartym Findling i wsp. (2011) przeprowadzili wśród dzieci z BD i symptomami manii. Badaniem objęto 96 dzieci w wieku 4-9 lat z diagnozą BD według DSM-IV i wynikiem w YMRS $\geq 15$. Dawkę aripiprazolu modyfikowano w zależności od odpowiedzi pacjenta (maksymalnie $15 \mathrm{mg} /$ dobę). Efekty terapii szacowano przy użyciu YMRS, CGI-S, CGAS oraz poprawionej skali oceny depresji wieku dziecięcego (Children's Depression Rating ScaleRevised, CDRS-R). Na pierwszorzędowy punkt końcowy składały się 3 z 4 kolejnych tygodni z wynikami: CDRS-R $<29$, YMRS $<10$ oraz CGAS $>50$. Lek podawano do 16 tygodni lub do czasu spełnienia pierwszorzędowego punktu końcowego. Średni czas trwania terapii aripiprazolem wynosił 12,5 tygodnia. Kryterium pierwszorzędowe skuteczności spełniło $62 \%$ badanych dzieci. Na końcu badania odnotowano istotną poprawę w wynikach YMRS, CDRS-R, CGAS oraz CGI-S. U 38\% badanych nie wykazano odpowiedzi na leczenie aripiprazolem (Findling et al., 2011).

Z kolei Biederman i wsp. (2007) przeprowadzili 8-tygodniowe otwarte, prospektywne badanie efektywności monoterapii aripiprazolem u młodych osób z BD $(n=19)$. Efektywność szacowano przy użyciu YMRS, CGI-I oraz krótkiej skali oceny psychiatrycznej (Brief Psychiatric Rating Scale, BPRS). Badanie ukończyło 15 pacjentów, u których w wyniku leczenia aripiprazolem $(9,4 \pm 4,2 \mathrm{mg} /$ dobę $)$ zaobserwowano istotną poprawę kliniczną, rozumianą jako redukcja w YMRS o $30 \%$. W innym badaniu młode osoby (8-17 lat) z epizodem manii lub mieszanym w przebiegu $\mathrm{BD}$ i ze współistniejącym ADHD otrzymywały aripiprazol $(n=18)$ lub placebo $(n=25)$ przez 6 tygodni. Pierwszorzędowe narzędzia oceny skuteczności stanowiły: YMRS oraz Swanson, Nolan and Pelham Teacher and Parent Rating Scale (SNAP-IV), służąca do oceny objawów ADHD, a drugorzędowe: CGI-S, skala oceny manii u dzieci przez rodziców (Child Mania Rating Scale-Parent Version, CMRS-P), CDRS-R i skala depresji Kutchera dla młodzieży (Kutcher Adolescent Depression Scale, KADS). W grupie leczonej aripiprazolem wykazano większą redukcję w YMRS, CMRS-P oraz CGI-S w porównaniu z grupą otrzymującą placebo. Nie zaobserwowano natomiast różnic pomiędzy obiema grupami pod względem remisji objawów depresji i ADHD (Tramontina et al., 2009). 
literature on the efficacy of using aripiprazole for treatment of BD in children and adolescents.

In contrast, Oh et al. (2013) compared the efficacy of aripiprazole with other atypical antipsychotics, i.e. risperidone, quetiapine, and paliperidone, in 127 patients (aged 4-18 years) with PBD in a retrospective study. The analysis referred to 127 patients, 62 of whom were treated with aripiprazole, 52 with risperidone, 11 with quetiapine and 2 with paliperidone. The severity of the disease and improvement of the health status were assessed using CGI-S and CGI-I, respectively, at the $1^{\text {st }}, 2^{\text {nd }}, 3^{\text {rd }}, 4^{\text {th }}$ and $5^{\text {th }}$ visit in the hospital. Patients treated with aripiprazole achieved lower scores in CGI-S compared with those treated with other atypical neuroleptics at the $2^{\text {nd }}$ and $3^{\text {rd }}$ hospital visits. However, the CGI-I results were lower only at the second visit. Based on the analysis, the authors conclude that aripiprazole may be more effective than other atypical antipsychotics in PBD, which suggests the need for a multicentre controlled trial.

\section{ADHD}

ADHD is a neurodevelopmental disorder characterised by problems with attention span, impulsivity and hyperactivity, which are disproportional to the age and development of the child (Bush, 2010). It may also be the first of several comorbid psychiatric disorders, which arise in the developmental age, or a state that increases the risk of developing antisocial behaviour, behaviours associated with substance use and of mood disorders (Nigg, 2013).

The effectiveness and impact of aripiprazole on cognitive functions in children with ADHD have been evaluated
Przegląd badań dotyczących skuteczności aripiprazolu w leczeniu BD u dzieci i młodzieży podano w tab. 1.

Natomiast Oh i wsp. (2013) porównali retrospektywnie skuteczność aripiprazolu z atypowymi lekami przeciwpsychotycznymi, tj. risperidonem, kwetiapiną i paliperidonem, u 127 pacjentów w wieku 4-18 lat z PBD. Analizą objęto 127 chorych, wśród których 62 leczono aripiprazolem, 52 risperidonem, 11 kwetiapiną, a 2 paliperidonem. Ciężkość choroby i poprawę stanu zdrowia oceniano odpowiednio za pomocą CGI-S i CGI-I podczas 1., 2., 3., 4. i 5. wizyty w szpitalu. W czasie 2. i 3. wizyty w szpitalu pacjenci leczeni aripiprazolem osiągali niższe wyniki w skali CGI-S w porównaniu z osobami otrzymującymi inne neuroleptyki atypowe. Natomiast w skali CGI-I mieli niższe wyniki tylko podczas 2. wizyty. $\mathrm{Z}$ dokonanej analizy autorzy wnioskują, iż aripiprazol może być efektywniejszy niż inne atypowe leki przeciwpsychotyczne w leczeniu PBD, sugerują też jednak konieczność przeprowadzenia wieloośrodkowego badania kontrolowanego.

\section{ADHD}

ADHD jest zaburzeniem neurorozwojowym, charakteryzującym się problemami z koncentracją uwagi, impulsywnością i nadruchliwością, które są niewspółmierne do wieku i rozwoju dziecka (Bush, 2010). Bywa też pierwszym z kilku współistniejących zaburzeń psychiatrycznych pojawiających się w trakcie rozwoju, stanem zwiększającym ryzyko rozwinięcia zachowań antyspołecznych, zachowań związanych z używaniem substancji psychoaktywnych czy zaburzeń nastroju (Nigg, 2013).

Skuteczność i wpływ aripiprazolu na funkcje poznawcze u dzieci $z$ ADHD oceniono $w$ otwartym

\begin{tabular}{|c|c|c|c|c|c|c|}
\hline $\begin{array}{l}\text { Author, year } \\
\text { Autor, rok }\end{array}$ & $\begin{array}{l}\text { Study design } \\
\text { Typ badania }\end{array}$ & $\begin{array}{c}\text { Number } \\
\text { of participants } \\
\text { Liczba uczestrików }\end{array}$ & $\begin{array}{c}\text { Age } \\
\text { Wiek uczestników }\end{array}$ & $\begin{array}{l}\text { Indications } \\
\text { Wskazania }\end{array}$ & $\begin{array}{l}\text { Treatment } \\
\text { duration } \\
\text { Czasleczenia }\end{array}$ & $\begin{array}{c}\text { Efficacy evaluation } \\
\text { methods } \\
\text { Skale oceniajace } \\
\text { efektywność }\end{array}$ \\
\hline Findling et al., 2009b & $\begin{array}{c}\text { Randomised, } \\
\text { double-blind } \\
\text { Randomizowane, } \\
\text { podwójnie zaślepione }\end{array}$ & 296 & $10-17$ & $\begin{array}{l}\text { BD, mixed or manic } \\
\quad \text { episodes } \\
B D, \text { epizod maniakalny } \\
\text { lub mieszany }\end{array}$ & $\begin{array}{l}4 \text { weeks } \\
4 \text { tygodnie }\end{array}$ & $\begin{array}{l}\text { YMRS, CGI-S, CGAS, } \\
\text { CDRS-R }\end{array}$ \\
\hline Findling et al., 2011 & $\begin{array}{l}\text { Open-label } \\
\text { Otwarte }\end{array}$ & 96 & $4-9$ & $\begin{array}{l}\text { BD with manic } \\
\text { symptoms } \\
\text { BD isymptomy manii }\end{array}$ & $\begin{array}{l}16 \text { weeks or until } \\
\text { reaching primary } \\
\text { efficacy endpoint } \\
\text { Do } 16 \text { tygodni lub } \\
\text { do czasu spetnienia } \\
\text { pierwszorzedowego } \\
\text { punktu końcowego }\end{array}$ & $\begin{array}{l}\text { YMRS, CGI-S, CGAS, } \\
\text { CDRS-R }\end{array}$ \\
\hline $\begin{array}{l}\text { Biederman et al., } \\
2007\end{array}$ & $\begin{array}{c}\text { Prospective, } \\
\text { open-label } \\
\text { Prospektywne, otwarte }\end{array}$ & 19 & $6-17$ & $\begin{array}{l}\text { BD type I and II } \\
\text { BD typu Iill }\end{array}$ & $\begin{array}{l}8 \text { weeks } \\
8 \text { tygodni }\end{array}$ & $\begin{array}{l}\text { BPRS, CDRS, CGIII, } \\
\text { YMRS }\end{array}$ \\
\hline $\begin{array}{l}\text { Tramontina et al., } \\
2009\end{array}$ & $\begin{array}{l}\text { Pilot, randomised } \\
\text { Pilotażowe, } \\
\text { randomizowane }\end{array}$ & 43 & $8-17$ & $\begin{array}{l}\text { BD (mixed or manic } \\
\text { episode) and ADHD } \\
B D \text { (epizod manii } \\
\text { lub mieszany) i ADHD }\end{array}$ & $\begin{array}{l}6 \text { weeks } \\
6 \text { tygodni }\end{array}$ & $\begin{array}{l}\text { YMRS, SNAP-IV, CGI-S, } \\
\text { CMRS-P, CDRS-R, } \\
\text { KADS }\end{array}$ \\
\hline
\end{tabular}

Tab. 1. Summary of literature evaluating efficacy of aripiprazole in treatment of BP in children and adolescents

Tab. 1. Badania oceniające skuteczność aripiprazolu w leczeniu BD u dzieci i młodzieży 
in an open pilot study (Findling et al., 2008b). The drug was administered to children (aged 8-12 years) with a mixed type of ADHD $(n=14)$ or with a predominance of attention deficit disorders $(n=9)$ at an average dose of $6.7 \mathrm{mg} /$ day for 6 weeks. The results of the therapy were measured using the ADHD Rating Scale-IV (ARS-IV), CGI and CGAS. At the end of the trial, the participants presented a significant reduction in ADHD symptoms and a functional improvement. However, no beneficial effect on cognition was observed.

\section{Pervasive developmental disorder}

Pervasive developmental disorder (PDD) is a group of disorders that appear in early childhood, where there are abnormalities in social relations, communication and an inflexible attachment to routinised patterns of thought and behaviour. According to International Statistical Classification of Diseases and Related Health Problems (ICD-10) classification, PDD includes, among others, autism, Asperger syndrome, childhood disintegrative disorder (CDD), also known as Heller's syndrome and Rett's syndrome. On the other hand, in DSM-5 classification, introduced by the American Psychiatric Association in 2013, the concept of multiple disorders was abandoned and subsumed under a single notion of autism spectrum disorder (ASD). People affected by ASD may experience irritability, tantrums, aggressive behaviours or self-aggression (Stigler et al., 2009). Currently, the FDA recommends aripiprazole for the treatment of irritability in children with ASD aged $>6$ years.

Short-term efficacy of aripiprazole in the treatment of irritability in children and adolescents with autistic disorder has been evaluated in two large clinical trials. In a randomised, double-blind, placebo-controlled study, which involved 218 autistic children (aged 6-17 years) presenting irritability, aggressiveness and behaviours leading to self-harm, aripiprazole was used for 8 weeks $(5,10$ or $15 \mathrm{mg} /$ day); the control groups used placebo (1:1:1:1). The effectiveness of the therapy was estimated using the Irritability subscale of the Aberrant Behavior Checklist (ABC-I) and CGI-I. At the end of the study, the treatment with aripiprazole (at any dose) resulted in a significant improvement in the ABC-I and CGI-I scales compared to placebo (Marcus et al., 2009). Similar results were obtained in another study, in which aripiprazole was used to treat irritability in 98 patients (aged 6-17 years) with autism. During 8 weeks, an individually adjusted dose of the drug was administered according to the needs of the patient (the target doses were 5, 10 and $15 \mathrm{mg} /$ day), which was compared to placebo. The average dose of aripiprazole at the end of the study was $8.6 \mathrm{mg} /$ day. The efficacy of the treatment was evaluated using the CGI-I, and the improvement in the ABC-I scale. Between the $1^{\text {st }}$ and the $8^{\text {th }}$ weeks of therapy, aripiprazole turned out to be more effective than placebo (Owen et al., 2009). badaniu pilotażowym (Findling et al., 2008b). Lek podawano dzieciom $\mathrm{w}$ wieku 8-12 lat $\mathrm{z}$ ADHD o typie mieszanym $(n=14)$ lub z przewagą zaburzeń koncentracji uwagi $(n=9)-\mathrm{w}$ dawce średnio $6,7 \mathrm{mg} /$ dobę przez 6 tygodni. Wyniki terapii mierzono za pomocą skali oceny nasilenia objawów ADHD (ADHD Rating Scale-IV, ARS-IV), CGI i CGAS. Na końcu próby u uczestników stwierdzono istotną redukcję objawów ADHD i poprawę funkcjonalną. Nie zaobserwowano jednak korzystnego wpływu leczenia aripiprazolem na funkcje poznawcze.

\section{Całościowe zaburzenia rozwojowe}

Całościowe zaburzenia rozwojowe (CZR) to grupa zaburzeń pojawiających się we wczesnym dzieciństwie, w ramach których występują nieprawidłowości w relacjach społecznych i komunikacji oraz nieelastyczne przywiązanie do zrutynizowanych wzorców myślenia i zachowania. Do CZR według Międzynarodowej Statystycznej Klasyfikacji Chorób i Problemów Zdrowotnych ICD-10 zalicza się m.in. autyzm dziecięcy, zespół Aspergera, zespół Hellera czy zespół Retta. Natomiast w klasyfikacji zaburzeń psychicznych Amerykańskiego Towarzystwa Psychiatrycznego DSM-5 - wprowadzonej w 2013 roku - zrezygnowano $\mathrm{z}$ wyodrębniania tych jednostek chorobowych i wprowadzono pojedyncze pojęcie ASD. U osób dotkniętych ASD mogą występować drażliwość, napady złości, zachowania agresywne lub autoagresywne (Stigler et al., 2009). Obecnie FDA rekomenduje aripiprazol w leczeniu drażliwości u dzieci powyżej 6. roku życia z ASD.

W dwóch dużych próbach klinicznych oceniono krótkoterminową skuteczność aripiprazolu w leczeniu drażliwości u dzieci i młodzieży z zaburzeniami autystycznymi. W badaniu randomizowanym, z podwójnie ślepą próbą i kontrolą placebo, którym objęto 218 dzieci autystycznych (6-17 lat) z drażliwością, agresywnością i zachowaniami prowadzącymi do samouszkodzeń, przez 8 tygodni stosowano aripiprazol $(5,10,15 \mathrm{mg} /$ dobę) lub placebo (1:1:1:1). Efektywność terapii szacowano przy użyciu podskali rozdrażnienia skali oceny zachowań autystycznych (Aberrant Behavior Checklist Irritability subscale, ABC-I) oraz CGI-I. Na końcu badania aripiprazol (niezależnie od dawki) powodował istotną poprawę w ABC-I i CGI-I w porównaniu z placebo (Marcus et al., 2009). Podobne wyniki uzyskano w innym badaniu, w którym aripiprazol stosowano w leczeniu drażliwości u 98 osób (6-17 lat) z autyzmem. Przez 8 tygodni podawano lek $\mathrm{w}$ dawce indywidualnie dobranej do potrzeb pacjenta (docelowo 5, 10, $15 \mathrm{mg} /$ dobę) lub placebo. Średnia dawka aripiprazolu na koniec badania wynosiła 8,6 mg/dobę. Skuteczność leku także oceniano przy pomocy ABC-I oraz CGI-I. Od 1. do 8. tygodnia terapii aripiprazol okazał się efektywniejszy niż placebo (Owen et al., 2009).

Przeprowadzono również naturalistyczne badanie otwarte skuteczności aripiprazolu, w którym uczestniczyło 
Also, an open naturalistic study on the efficacy of aripiprazole, attended by 5 boys (aged 5-18 years) with DPP, has been conducted. The subjects received the drug at a dose of 10-15 mg/day for 8-16 weeks (mean duration 12 weeks). The response to treatment, assessed using the CGI-I, was referred to as "much improved" or "very much improved" for all participants (Stigler et al., 2004). The high therapeutic effectiveness of aripiprazole in the PDD has also been confirmed by the results of an open-label study conducted among 25 patients with Asperger syndrome or PDD (a diagnosis based on DSM-IV-TR classification) aged 5-17 years. The patients were treated with the drug at a mean dose $7.8 \mathrm{mg}$ for 14 weeks. The remission criterion was "much improved" or "very much improved" in the CGI-I and a reduction in the ABC-I by at least $25 \%$. In this study, 22 participants $(88 \%)$ responded to treatment with aripiprazole (Stigler et al., 2009).

Moreover, a prospective randomised clinical trial conducted by Ghanizadeh et al. in 2014 evaluated safety and efficacy of aripiprazole in children and adolescents with ASD compared with risperidone. In the period of 2 months, both drugs induced a significant decrease in outcomes of Aberrant Behavior Checklist (ABC) scale. Safety and efficacy of aripiprazole (average dose $5.5 \mathrm{mg} / 24 \mathrm{~h}$ ) and risperidone (average dose $1.12 \mathrm{mg} / 24 \mathrm{~h}$ ) proved to be comparable, and the adverse event rate did not differ significantly, either. In conclusion, the authors of the study suggest that the choice between aripiprazole and risperidone in patients with ASD should be based on the clinical profile and personal preferences of the patient.

\section{Tics}

Tics are usually stereotyped, involuntary repetitive movements or sounds that can be preceded by prodromal symptoms (e.g. an increase in muscle tone) (Shprecher and Kurlan, 2009). Less common are sensory tics, specifically located in a particular part of the body, perceived as tingling, itching, burning or numbness, and so-called phantom tics (felt inside other people or objects and passing through their touch or scratch). The neuropsychiatric disorder characterised by the presence of both motor and vocal tics is called GTS. The aetiology of tics takes into account genetic factors as well as structural and functional changes in the brain, disorders of neurotransmission, especially dopaminergic, and psychological factors. The prevalence of transient tic disorder among schoolage children is $4-24 \%$, and the prevalence of chronic tics is $0.1-0.3 \%$. In turn, the incidence of GTS in children and adolescents is estimated to be approximately $0.6 \%$ (Bryńska and Wolańczyk, 2010). Because of tics, patients may experience a variety of emotional and educational problems as well as difficulties in their peer relationships. Tics are rarely an isolated symptom. In some young patients, a tic disorder is concomitant with ADHD, or obsessive-compulsive disorder.
5 chłopców (5-18 lat) z CZR. Badani otrzymywali lek w dawce $10-15 \mathrm{mg}$ /dobę przez 8-16 tygodni (średnio 12 tygodni). Odpowiedź na leczenie u wszystkich uczestników - ocenioną przy pomocy CGI-I - określono jako „dobrą” lub „bardzo dobrą” (Stigler et al., 2004). Wysoką efektywność terapeutyczną aripiprazolu w CZR potwierdzają także wyniki otwartego badania przeprowadzonego u 25 osób z zespołem Aspergera lub CZR [diagnoza postawiona na podstawie kryteriów zrewidowanej klasyfikacji DSM-IV (DSM-IV-TR)] w wieku 5-17 lat. Pacjentom podawano lek w średniej dawce 7,8 mg przez 14 tygodni. Kryterium remisji stanowiła „poprawa” lub „bardzo duża poprawa" w CGI-I oraz redukcja w ABC-I o co najmniej 25\%. U 22 uczestników badania (88\%) stwierdzono odpowiedź na leczenie aripiprazolem (Stigler et al., 2009).

Z kolei Ghanizadeh i wsp. (2014) w prospektywnym randomizowanym badaniu klinicznym sprawdzili skuteczność i bezpieczeństwo aripiprazolu w porównaniu $\mathrm{z}$ risperidonem u dzieci i młodzieży z ASD. W ciągu 2 miesięcy stosowanie obu leków wpłynęło na obniżenie wyników w skali Aberrant Behavior Checklist (ABC). Bezpieczeństwo oraz skuteczność aripiprazolu (średnia dawka: 5,5 mg/dobę) i risperidonu (średnia dawka: 1,12 mg/dobę) okazały się porównywalne, a wskaźnik występowania działań niepożądanych w wyniku stosowanych leków znacząco się nie różnił. Autorzy badania sugerują, że wybór pomiędzy aripiprazolem a risperidonem w leczeniu drażliwości u osób z ASD powinien więc opierać się na profilu klinicznym leku oraz preferencjach pacjenta.

\section{Tiki}

Tiki najczęściej są stereotypowymi, powtarzalnymi ruchami mimowolnymi lub dźwiękami, które mogą poprzedzać objawy zwiastunowe (np. wzrost napięcia mięśniowego) (Shprecher i Kurlan, 2009). Rzadziej występują tiki czuciowe, wyraźnie zlokalizowane w konkretnej części ciała i odczuwane jako mrowienie, swędzenie, pieczenie czy drętwienie, oraz tzw. tiki fantomowe (odczuwane wewnątrz innych ludzi lub przedmiotów, ustępujące po ich dotknięciu lub podrapaniu). Zaburzenie neuropsychiatryczne charakteryzujące się występowaniem zarówno tików ruchowych, jak i wokalnych nosi nazwę zespołu GTS. W etiologii zaburzeń tikowych bierze się pod uwagę czynniki genetyczne, zmiany strukturalne i funkcjonalne mózgu, zaburzenia neuroprzewodnictwa (zwłaszcza dopaminy) oraz czynniki psychologiczne. Rozpowszechnienie tików przejściowych wśród dzieci w wieku szkolnym wynosi 4-24\%, a tików przewlekłych - 0,1-0,3\%. Z kolei występowanie GTS u dzieci i młodzieży szacuje się na około 0,6\% (Bryńska i Wolańczyk, 2010). Z powodu tików chorzy mogą doświadczać różnych problemów emocjonalnych, edukacyjnych, a także trudności w relacjach $\mathrm{z}$ rówieśnikami. Tiki rzadko są objawem izolowanym. U części młodych pacjentów obserwuje się współwystępowanie zaburzeń tikowych z ADHD czy zaburzeniami obsesyjno-kompulsywnymi. 
The FDA recommends aripiprazole for the treatment of GTS in children aged $>6$ years. In a 10 -week double-blind, placebo-controlled multicentre study, a short-term efficacy of aripiprazole was evaluated in children and adolescents with GTS $(n=61)$ aged $6-18$ years, diagnosed according to DSM-IV criteria and with the result in Yale Global Tic Severity Scale (YGTTS) $\geq 22$. Aripiprazole turned out to be more effective than placebo, which resulted from a YGTSS score reduction and the frequency of response in the CGI-I at the level of $66 \%$ in the group receiving aripiprazole compared to $45 \%$ in the placebo group (Yoo et al., 2013). The effectiveness of aripiprazole in reducing the severity and frequency of tics was confirmed in a 12-week open trial, which included 15 patients aged 7-19 years with GTS or a chronic tic disorder. The improvement in YGTSS, CGI-I and GCI-S scales was observed starting from the $3^{\text {rd }}$ week of treatment with the drug at doses individually matched to patients' needs (Seo et al., 2008).

In a randomised double-blind trial of safety and efficacy of aripiprazole and risperidone in treatment of tic disorders in children and adolescents, a significant decrease in YGTSS scale was observed after two months of treatment. Both aripiprazole and risperidone were well-tolerated by the participants of the study. Side effects were comparable, and both drugs affected health-related life quality in similar way. However, risperidone increased the patients' social functioning more than aripiprazole in short term (Ghanizadeh and Haghighi, 2014).

\section{Aggressive behaviour}

Aggressive behaviours in children and adolescents may be a symptom of various somatic diseases (tumours, trauma, inflammation, diseases of the thyroid gland) and mental disorders. It has been suggested that the incidence of aggressive behaviour in childhood can cause health problems in the future, difficulties in learning, poverty and risky sexual behaviours (Temcheff et al., 2011).

In a 15-day open trial of the efficacy of aripiprazole in children and adolescents with conduct disorder, the authors recruited 12 children (aged 6-12 years) and 11 adolescents (aged 13-17 years) with a conduct disorder and the score of 2-3 in the Rating of Aggression Against People and/or Property (RAAPP). Aripiprazole was administered at a dose of $1 \mathrm{mg}$ /day to patients having a body weight $<25 \mathrm{~kg}$, at a dose of $2 \mathrm{mg} /$ day to patients with body weight $25-50 \mathrm{~kg}$, at a dose of $5 \mathrm{mg} /$ day to patients with body weight $50-70 \mathrm{~kg}$ and at a dose of $10 \mathrm{mg} /$ day to patients with body weight $>70 \mathrm{~kg}$. A significant improvement in the RAAPP and CGI-S scales was found in both age groups (Findling et al., 2009a). Moreover, in a non-randomised, open-label study, 36 patients aged $11.9 \pm 2.6$ years with various disabilities and aggressive behaviour were treated with aripiprazole and ziprasidone, and the efficacy of both drugs was compared. The participants were diagnosed using a Mini International Neuropsychiatric Interview (MINI), and the results were
Aripiprazol jest rekomendowany przez FDA w leczeniu GTS u dzieci powyżej 6. roku życia. W 10-tygodniowym wieloośrodkowym badaniu z podwójnie ślepą próbą i kontrolą placebo została oceniona krótkoterminowa skuteczność aripiprazolu u dzieci i młodzieży w wieku 6-18 lat z GTS zdiagnozowanym według kryteriów DSM-IV ( $n=61)$ oraz wynikiem w globalnej skali nasilenia tików (Yale Global Tic Severity Scale, YGTSS) $\geq 22$. Aripiprazol okazał się skuteczniejszy od placebo, co wynikało z redukcji w YGTSS i częstości odpowiedzi w CGI-I na poziomie 66\% w grupie leczonej aripiprazolem - wobec $45 \%$ u osób otrzymujących placebo (Yoo et al., 2013). Efektywność aripiprazolu w redukcji ciężkości i częstotliwości objawów tikowych potwierdzono w 12-tygodniowej próbie otwartej, którą objęto 15 osób w wieku 7-19 lat z GTS lub przewlekłą chorobą tikową. Poprawę w YGTSS, CGI-I oraz CGI-S obserwowano od 3. tygodnia podawania leku w dawkach indywidualnie dobieranych do potrzeb pacjentów (Seo et al., 2008). $\mathrm{Z}$ kolei w randomizowanym, podwójnie zaślepionym badaniu porównującym skuteczność i bezpieczeństwo aripiprazolu $\mathrm{z}$ risperidonem u dzieci i młodzieży $\mathrm{z}$ tikami stosowanie przez 2 miesiące tych leków obniżało wyniki w skali YGTSS. Uczestnicy badania dobrze tolerowali zarówno aripiprazol, jak i risperidon. Objawy niepożądane okazały się porównywalne, a oba leki wpływały podobnie na jakość życia związaną ze stanem zdrowiem. Jednak w porównaniu $\mathrm{z}$ aripiprazolem risperidon $\mathrm{w}$ krótkim czasie bardziej poprawił społeczne funkcjonowanie pacjentów z tikami (Ghanizadeh i Haghighi, 2014).

\section{Zachowania agresywne}

Zachowania agresywne u dzieci i młodzieży mogą być objawem różnych chorób somatycznych (guzy, urazy, stany zapalne, choroby tarczycy) oraz zaburzeń psychicznych. Sugeruje się, że występowanie zachowań agresywnych $\mathrm{w}$ dzieciństwie może w przyszłości stanowić przyczynę problemów zdrowotnych, kłopotów w nauce, ubóstwa czy ryzykownych zachowań seksualnych (Temcheff et al., 2011). W 15-dniowej próbie otwartej oceniono skuteczność aripiprazolu u dzieci i młodzieży z zaburzeniami zachowania. Badaniem objęto 12 dzieci (6-12 lat) i 11 adolescentów (13-17 lat) z zaburzeniami zachowania i wynikiem 2-3 w skali agresji (Rating of Aggression Against People and/or Property, RAAPP). Aripiprazol podawano w dawce $1 \mathrm{mg} /$ dzień osobom o masie ciała $<25 \mathrm{~kg}, 2 \mathrm{mg} /$ dzień osobom o masie ciała $25-50 \mathrm{~kg}, 5 \mathrm{mg} / \mathrm{dzień} \mathrm{osobom} \mathrm{o} \mathrm{ma-}$ sie ciała $50-70 \mathrm{~kg}$ oraz $10 \mathrm{mg} /$ dzień u pacjentów $>70 \mathrm{~kg}$. $\mathrm{W}$ obu grupach wiekowych stwierdzono istotną poprawę w skalach RAAPP i CGI-S (Findling et al., 2009a).

Z kolei w nierandomizowanym, otwartym badaniu 36 pacjentów w wieku 11,9 \pm 2,6 roku z różnymi schorzeniami i zachowaniami agresywnymi porównano skuteczność aripiprazolu i ziprazidonu. Uczestnicy byli diagnozowani za pomocą kwestionariusza oceny neuropsychiatrycznej (Mini International Neuropsychiatric Interview, MINI), a wyniki 
measured using the Overt Aggression Scale (OAS). There were no statistically significant differences between the groups receiving aripiprazole and ziprasidone, and the mean improvement in the OAS was 63\% (Bastiaens, 2009). However, no comparative studies addressing safety and efficacy of aripiprazole and risperidone in the treatment of irritability in children and adolescents with aggressive behaviour have been found.

\section{SAFETY AND TOLERABILITY}

Aripiprazole evaluated in clinical trials among children and adolescents showed a good safety and tolerability profile. The incidence and type of side effects of aripiprazole in the paediatric population is essentially similar to those observed in adults. However, by contrast with adults, adolescents treated with aripiprazole more often develop such side effects as drowsiness, sedation, EPS, dry mouth, increased appetite, and orthostatic hypotension. In a study conducted by Findling et al. (2008a) in patients with schizophrenia (aged 13-17 years), side effects most frequently observed were EPS, drowsiness and tremor. The incidence of these side effects is dependent on the dose (Findling et al., 2008a). On the other hand, children with BD type I with acute manic or mixed symptoms (aged 4-9 years) had the following side effects: abdominal pain, increased appetite and headache. Two patients discontinued the clinical trial because of akathisia and epistaxis (Findling et al., 2011). In the study of Woods et al. (2007), the most common side effect observed among the participants was akathisia, and the average score in the Barnes Akathisia Scale (BAS) fell down to the baseline at the last visit. In children with ADHD treated with aripiprazole, the main reported adverse reactions were sedation and headache (Findling et al., 2008b). Sedation was also the most commonly reported side effect observed among patients treated for aggressive behaviours coexisting with different diagnoses (Bastiaens, 2009). In a short-term study evaluating the treatment of irritability in children with ASD, the most common symptoms that led to treatment discontinuation were sedation, excessive salivation and tremors (Blankenship et al., 2010; Marcus et al., 2009). In another study performed among patients with autistic disorders, EPS was reported in $14.9 \%$ of those taking aripiprazole and in $8 \%$ of the participants in the placebo group (Blankenship et al., 2010; Owen et al., 2009). Moreover, in an open trial involving boys with PDD aged of 5-18 years, 2 out of 5 patients reported sleepiness (Blankenship et al., 2010; Stigler et al., 2004), and in a study on adolescents with Asperger syndrome and PDD (diagnosis based on DSM-IV-TR classification), mild EPS occurred in 9 out of 25 people (Blankenship et al., 2010; Stigler et al., 2009). In the study by Marcus et al. (2011a, 2011b), 286 of 330 patients reported the following side effects: weight gain, vomiting, inflammation of the nasopharynx, increased appetite, fever, upper respiratory tract infections, and insomnia. The most common side effects because of which patients mierzono przy użyciu skali jawnej agresji (Overt Aggression Scale, OAS). Nie odnotowano żadnych istotnych statystycznie różnic pomiędzy grupami przyjmującymi aripiprazol i ziprazidon, a średnia poprawa w OAS wynosiła $63 \%$ (Bastiaens, 2009). Nie znaleziono natomiast badań porównujących skuteczność aripiprazolu $\mathrm{z}$ risperidonem w populacji dzieci i młodzieży z zachowaniami agresywnymi.

\section{BEZPIECZEŃSTWO I TOLERANCJA}

Aripiprazol w próbach klinicznych wśród dzieci i młodzieży wykazywał dobry profil bezpieczeństwa i tolerancji. Częstość występowania i rodzaj działań niepożądanych aripiprazolu w populacji pediatrycznej są zasadniczo podobne jak w przypadku osób dorosłych. Jednak u młodzieży leczonej aripiprazolem częściej niż u dorosłych mogą się pojawiać efekty uboczne, takie jak senność, sedacja, OPP, suchość w jamie ustnej, wzrost apetytu i niedociśnienie ortostatyczne. W badaniu przeprowadzonym przez Findlinga i wsp. (2008a) wśród chorych na schizofrenię (13-17 lat) najczęściej obserwowano OPP, senność i drżenie. Częstość występowania tych działań ubocznych zależy od wielkości przyjmowanej dawki (Findling et al., 2008a). Z kolei u dzieci z BD typu I z ostrym epizodem manii lub mieszanym (4-9 lat) odnotowano takie efekty uboczne, jak bóle brzucha, wzrost apetytu i bóle głowy. Dwóch pacjentów przerwało tę próbę kliniczną z powodu wystąpienia akatyzji i krwawienia $\mathrm{z}$ nosa (Findling et al., 2011). W badaniu Woodsa i wsp. (2007) najczęstszym objawem niepożądanym obserwowanym wśród uczestników była właśnie akatyzja, przy czym podczas ostatniej wizyty średni wynik w skali akatyzji Barnesa (Barnes Akathisia Scale, BAS) spadł do poziomu wyjściowego. U dzieci z ADHD leczonych aripiprazolem głównymi zgłaszanymi objawami niepożądanymi były sedacja i bóle głowy (Findling et al., 2008b). Sedacja stanowiła też najczęściej rejestrowane działanie uboczne w badaniu przeprowadzonym wśród pacjentów leczonych z powodu zachowań agresywnych współistniejących z różnymi innymi diagnozami (Bastiaens, 2009). W krótkoterminowym badaniu oceniającym leczenie drażliwości u dzieci z ASD najczęstszymi objawami, z powodu których przerywano leczenie, były sedacja, nadmierne ślinienie i drżenie (Blankenship et al., 2010; Marcus et al., 2009). W innym badaniu - przeprowadzonym także wśród pacjentów z ASD - OPP zgłaszało 14,9\% osób przyjmujących aripiprazol i $8 \%$ $\mathrm{w}$ grupie otrzymującej placebo (Blankenship et al., 2010; Owen et al., 2009). Z kolei w próbie otwartej, obejmującej chłopców z CZR w wieku 5-18 lat, 2 z 5 osób zgłosiły senność (Blankenship et al., 2010; Stigler et al., 2004), a w badaniu adolescentów z zespołem Aspergera i CZR (diagnoza postawiona na podstawie kryteriów DSM-IV-TR) łagodne OPP wystąpiły u 9 z 25 osób (Blankenship et al., 2010; Stigler et al., 2009). W badaniu Marcusa i wsp. (2011a, 2011b) u 286 z 330 pacjentów wystąpiły takie objawy niepożądane, jak wzrost masy ciała, wymioty, zapalenie jamy nosowo-gardłowej, zwiększenie apetytu, gorączka, infekcje górnych 
The results of studies done so far suggest, that aripiprazole therapy does not increase prolactin levels (Kumar et al., 2013). In the population of children and adolescents with schizophrenia, PDD and GTS, a decrease in the average value of prolactin was observed (Findling et al., 2008a; Stigler et al., 2009; Yoo et al., 2013). Cases of low serum prolactin levels were found more often in boys than in girls treated with aripiprazole for BD or schizophrenia (Findling et al., 2008a; Greenaway and Elbe, 2009).

The results of some clinical trials suggest that aripiprazole may cause weight gain in children and adolescents. According to the study by Findling et al. (2008a) involving schizophrenia in adolescent patients, the average change in body weight was $-0.8 \mathrm{~kg}, 0.0 \mathrm{~kg}$ and $+0.2 \mathrm{~kg}$ for the placebo group, the group treated with $10 \mathrm{mg}$ and with $30 \mathrm{mg}$ of aripiprazole, respectively. However, in children and adolescents treated for $\mathrm{BD}$, the weight change was $+0.56 \mathrm{~kg}$, $+0.82 \mathrm{~kg}$, and $+1.08 \mathrm{~kg}$ for the placebo group, patients treated with $10 \mathrm{mg}$ and $30 \mathrm{mg}$ of aripiprazole, respectively (Findling et al., 2009b). In the study by Woods et al. (2007) an average weight gain of $1.2 \mathrm{~kg}$ was observed in patients with prodromal symptoms treated with aripiprazole. An increase in average body weight was also observed in the treatment of people with GTS (Yoo et al., 2013). In children with autistic disorder, the average weight increase was $2 \mathrm{~kg}$ in patients receiving aripiprazole and $0.8 \mathrm{~kg}$ in the placebo group in the 8 th week of treatment (Blankenship et al., 2010; Owen et al., 2009). In the study by Marcus et al. (2011a, 2011b), weight gain was one of the most frequently reported adverse events, and it was the reason for discontinuation in some patients. The authors therefore suggested that body weight should be monitored in the long-term treatment with aripiprazole.

Most studies conducted to date indicate that the use of aripiprazole does not cause dyslipidaemia (Kumar et al., 2013). The results of the first 14-week open prospective study published in 2012 indicate that the treatment with aripiprazole in children and adolescents is not associated with cardiac risk and sudden unexplained death (Ho et al., 2012). An analysis of electrocardiograms of patients (aged 5-17 years) with PDD treated for irritability with aripiprazole (2.5-15 mg) showed no significant changes in PR, QRS, RR and QTc after treatment. There was also no correlation between the dose and the percentage change in QTc. The length of QTc did not exceed $440 \mathrm{~ms}$ in any person after the treatment (Ho et al., 2012).

\section{CONCLUSIONS}

Not all psychiatric diseases in the paediatric population can be treated with psychotherapy. The broad spectrum of psychiatric disorders in children and adolescents require medical treatment, including the use of antipsychotic drugs. When deciding on the inclusion of antipsychotics in young people, we should carefully examine the benefit to risk ratio, because it seems that there is a greater risk dróg oddechowych oraz bezsenność. Najczęstszymi objawami niepożądanymi, z powodu których chorzy przerywali leczenie, były agresja i przyrost wagi.

Wyniki dotychczasowych badań wskazują na to, że terapia aripiprazolem zasadniczo nie powoduje wzrostu poziomu prolaktyny (Kumar et al., 2013). W populacji dzieci i młodzieży ze schizofrenią, CZR czy GTS zaobserwowano jednak spadek średniej wartości prolaktyny (Findling et al., 2008a; Stigler et al., 2009; Yoo et al., 2013). Przypadki małego stężenia prolaktyny w surowicy stwierdzono częściej u chłopców niż u dziewcząt leczonych aripiprazolem z powodu BD lub schizofrenii (Findling et al., 2008a; Greenaway i Elbe, 2009). Rezultaty niektórych prób klinicznych wskazują, że aripiprazol może powodować przyrost masy ciała $\mathrm{u}$ dzieci i młodzieży. W badaniu Findlinga i wsp. (2008a) po leczeniu adolescentów ze schizofrenią średnia zmiana masy ciała wynosiła $-0,8 \mathrm{~kg}, 0,0 \mathrm{~kg} \mathrm{i}+0,2 \mathrm{~kg}$ odpowiednio dla grupy otrzymującej placebo, $10 \mathrm{mg}$ i $30 \mathrm{mg}$ aripiprazolu. Natomiast u dzieci i młodzieży z BD zmiana masy ciała wynosiła $+0,56 \mathrm{~kg},+0,82 \mathrm{~kg} \mathrm{i}+1,08 \mathrm{~kg}$ odpowiednio dla placebo, $10 \mathrm{mg}$ i $30 \mathrm{mg}$ aripiprazolu (Findling et al., 2009b). Z kolei w badaniu Woodsa i wsp. (2007) zaobserwowano średni przyrost masy ciała o 1,2 kg u pacjentów z objawami prodromalnymi leczonych aripiprazolem. Także podczas leczenia osób z GTS zaobserwowano wzrost średniej masy ciała (Yoo et al., 2013). U dzieci z ASD w 8. tygodniu terapii średni przyrost wagi wynosił $2 \mathrm{~kg}$ w grupie aripiprazolu i $0,8 \mathrm{~kg}$ w grupie placebo (Blankenship et al., 2010; Owen et al., 2009). W badaniu Marcusa i wsp. (2011a, 2011b) zwiększenie masy ciała było jednym z najczęściej zgłaszanych objawów niepożądanych i przyczyną przerwania badania przez niektórych pacjentów. Autorzy zasugerowali więc, aby przy długoterminowym leczeniu aripiprazolem monitorować wagę.

Większość przeprowadzonych dotychczas badań dowodzi tego, że stosowanie aripiprazolu nie powoduje dyslipidemii (Kumar et al., 2013).

Opublikowane w 2012 roku wyniki pierwszego, 14-tygodniowego otwartego badania prospektywnego wskazują, iż terapia aripiprazolem u dzieci i młodzieży nie wiąże się z ryzykiem wystąpienia zaburzeń serca i nagłej niewyjaśnionej śmierci (Ho et al., 2012). Analiza elektrokardiogramów chorych (5-17 lat) z CZR - wykonywanych z powodu drażliwości nie wykazała po terapii aripiprazolem $(2,5-15 \mathrm{mg}) \dot{z}$ adnych istotnych zmian w odcinkach PR, QRS, RR oraz QTc. Nie stwierdzono także żadnej korelacji pomiędzy podaną dawką a procentowością zmian w QTc. U żadnej osoby po leczeniu długość QTc nie przekroczyła 440 ms (Ho et al., 2012).

\section{PODSUMOWANIE}

Nie wszystkie choroby psychiatryczne w populacji pediatrycznej mogą być leczone psychoterapeutycznie. Szerokie spektrum zaburzeń psychiatrycznych u dzieci i młodzieży wymaga leczenia farmakologicznego, w tym zastosowania leków przeciwpsychotycznych. Decydując się na włączenie neuroleptyków do terapii młodych osób, należy dokładnie 
of side effects in this group of patients. The side effects of antipsychotic drugs (i.e. weight gain, sedation, akathisia) are important causes of treatment discontinuation among patients. A greater risk of side effects may also be crucial in the context of the decision to continue treatment in the group of children and adolescents (Kirino, 2012). It is indicated that atypical antipsychotics are better tolerated by young people when compared to classical neuroleptics, and thus they are more frequently used in the treatment of psychiatric disorders in the paediatric population. It appears that aripiprazole, because of its favourable metabolic profile, may play an important role in the treatment of psychiatric disorders in children and adolescents. Still, the amount of research on the effectiveness of aripiprazole treatment in the paediatric population is limited (currently, there are no Polish trials evaluating efficacy of aripiprazole in this age group). Further studies on the use of this drug in psychiatric disorders in children and adolescents are therefore recommended.

\section{Conflict of interest}

The authors do not report any financial or personal links to other persons or organisations that might negatively affect the content of this publication and/or claim rights thereto.

\section{References / Piśmiennictwo}

Algon S, Yi J, Calkins ME et al.: Evaluation and treatment of children and adolescents with psychotic symptoms. Curr Psychiatry Rep 2012; 14: 101-110.

Asarnow RF, Forsyth JK: Genetics of childhood-onset schizophrenia. Child Adolesc Psychiatr Clin N Am 2013; 22: 675-687.

Axelson D, Birmaher B, Strober M et al.: Phenomenology of children and adolescents with bipolar spectrum disorders. Arch Gen Psychiatry 2006; 63: 1139-1148.

Bastiaens L: A non-randomized, open study with aripiprazole and ziprasidone for the treatment of aggressive behavior in youth in a community clinic. Community Ment Health J 2009; 45: 73-77.

Biederman J, Mick E, Spencer T et al.: An open-label trial of aripiprazole monotherapy in children and adolescents with bipolar disorder. CNS Spectr 2007; 12: 683-689.

Blankenship K, Erickson CA, Stigler KA et al.: Aripiprazole for irritability associated with autistic disorder in children and adolescents aged 6-17 years. Ped Health 2010; 4: 375-381.

Bolonna AA, Kerwin RW: Partial agonism and schizophrenia. Br J Psychiatry 2005 ; 186: 7-10.

Bryńska A, Wolańczyk T: Dziecko z zaburzeniami tikowymi w szkole i przedszkolu. Ośrodek Rozwoju Edukacji, Warszawa 2010.

Bush G: Attention-deficit/hyperactivity disorder and attention networks. Neuropsychopharmacology 2010; 35: 278-300.

DeLeon A, Patel NC, Crismon ML: Aripiprazole: a comprehensive review of its pharmacology, clinical efficacy, and tolerability. Clin Ther 2004; 26: 649-666.

Driver DI, Gogtay N, Rapoport JL: Childhood onset schizophrenia and early onset schizophrenia spectrum disorders. Child Adolesc Psychiatr Clin N Am 2013; 22: 539-555.

Esposito-Smythers C, Birmaher B, Valeri S et al.: Child comorbidity, maternal mood disorder, and perceptions of family functioning among bipolar youth. J Am Acad Child Adolesc Psychiatry 2006; 45: 955-964

Findling RL, Kauffman R, Sallee FR et al.: An open-label study of aripiprazole: pharmacokinetics, tolerability, and effectiveness in children przeanalizować współczynnik korzyści względem ryzyka - wydaje się bowiem, że w tej grupie pacjentów istnieje większe ryzyko wystąpienia objawów niepożądanych. Skutki uboczne leków przeciwpsychotycznych (takie jak przyrost wagi, sedacja, akatyzja) są ważnymi przyczynami przerywania leczenia przez pacjentów. Większe ryzyko wystąpienia objawów niepożądanych może mieć również duże znaczenie przy podejmowaniu decyzji o kontynuacji leczenia u dzieci i młodzieży (Kirino, 2012). Wskazuje się na to, że atypowe leki przeciwpsychotyczne są przez młode osoby lepiej tolerowane niż neuroleptyki klasyczne - i przez to częściej się je stosuje w leczeniu zaburzeń psychiatrycznych w populacji pediatrycznej. Wydaje się, że aripiprazol - z powodu swojego korzystniejszego profilu metabolicznego - może odgrywać istotną rolę w leczeniu zaburzeń psychiatrycznych u dzieci i młodzieży. Nadal jednak liczba badań dotyczących skuteczności leczenia aripiprazolem w tej grupie wiekowej jest ograniczona (nie znaleziono również polskich badań oceniających to działanie). Dlatego wskazane wydaje się podejmowanie dalszych badań efektywności leku w terapii zaburzeń psychicznych u dzieci i młodzieży.

\section{Konflikt interesów}

Autorzy nie zgłaszaja żadnych finansowych ani osobistych powiązań $z$ innymi osobami lub organizacjami, które moglyby negatywnie wplynać na treść publikacji oraz rościć sobie prawo do tej publikacji.

and adolescents with conduct disorder. J Child Adolesc Psychopharmacol 2009a; 19: 431-439.

Findling RL, McNamara NK, Youngstrom EA et al.: An open-label study of aripiprazole in children with a bipolar disorder. J Child Adolesc Psychopharmacol 2011; 21:345-351.

Findling RL, Nyilas M, Forbes RA et al.: Acute treatment of pediatric bipolar I disorder, manic or mixed episode, with aripiprazole: a randomized, double-blind, placebo-controlled study. J Clin Psychiatry 2009b; 70: 1441-1451.

Findling RL, Robb A, Nyilas M et al.: A multiple-center, randomized, double-blind, placebo-controlled study of oral aripiprazole for treatment of adolescents with schizophrenia. Am J Psychiatry 2008a; 165: 1432-1441.

Findling RL, Short EJ, Leskovec T et al.: Aripiprazole in children with attention-deficit/hyperactivity disorder. J Child Adolesc Psychopharmacol 2008b; 18: 347-354.

Gardner DM, Baldessarini RJ, Waraich P: Modern antipsychotic drugs: a critical overview. CMAJ 2005; 172: 1703-1711.

Ghanizadeh A, Haghighi A: Aripiprazole versus risperidone for treating children and adolescents with tic disorder: a randomized double blind clinical trial. Child Psychiatry Hum Dev 2014; 45: 596-603.

Ghanizadeh A, Sahraeizadeh A, Berk M: A head-to-head comparison of aripiprazole and risperidone for safety and treating autistic disorders, a randomized double blind clinical trial. Child Psychiatry Hum Dev 2014; 45: 185-192.

Greenaway M, Elbe D: Focus on aripiprazole: a review of its use in child and adolescent psychiatry. J Can Acad Child Adolesc Psychiatry 2009; 18: 250-260.

Hirose T, Kikuchi T: Aripiprazole, a novel antipsychotic agent: dopamine $\mathrm{D}_{2}$ receptor partial agonist. J Med Invest 2005; 52 Suppl: 284-290.

Ho JG, Caldwell RL, McDougle CJ et al.: The effects of aripiprazole on electrocardiography in children with pervasive developmental disorders. J Child Adolesc Psychopharmacol 2012; 22: 277-283.

Kirino E: Efficacy and safety of aripiprazole in child and adolescent patients. Eur Child Adolesc Psychiatry 2012; 21: 361-368.

Kumar A, Datta SS, Wright SD et al.: Atypical antipsychotics for psychosis in adolescents. Cochrane Database Syst Rev 2013; (10): CD009582. 
Leibenluft E: Severe mood dysregulation, irritability, and the diagnostic boundaries of bipolar disorder in youths. Am J Psychiatry 2011; 168: 129-142.

Lewinsohn PM, Klein DN, Seeley JR: Bipolar disorder during adolescence and young adulthood in a community sample. Bipolar Disord 2000; 2: 281-293.

Mailman RB, Murthy V: Third generation antipsychotic drugs: partial agonism or receptor functional selectivity? Curr Pharm Des 2010; 16: $488-501$.

Marcus RN, Owen R, Kamen L et al.: A placebo-controlled, fixed-dose study of aripiprazole in children and adolescents with irritability associated with autistic disorder. J Am Acad Child Adolesc Psychiatry 2009; 48: 1110-1119.

Marcus RN, Owen R, Manos G et al.: Aripiprazole in the treatment of irritability in pediatric patients (aged 6-17 years) with autistic disorder: results from a 52-week, open-label study. J Child Adolesc Psychopharmacol 2011a; 21: 229-236.

Marcus RN, Owen R, Manos G et al.: Safety and tolerability of aripiprazole for irritability in pediatric patients with autistic disorder a 52-week, open-label, multicenter study. J Clin Psychiatry 2011b; 72: $1270-1276$.

Nigg JT: Attention-deficit/hyperactivity disorder and adverse health outcomes. Clin Psychol Rev 2013; 33: 215-228.

Oh J, Chang JG, Lee SB et al.: Comparison of aripiprazole and other atypical antipsychotics for pediatric bipolar disorder: a retrospective chart review of efficacy and tolerability. Clin Psychopharmacol Neurosci 2013; 11: 72-79.

Owen R, Sikich L, Marcus RN et al.: Aripiprazole in the treatment of irritability in children and adolescents with autistic disorder. Pediatrics 2009; 124: 1533-1540.

Perlis RH, Miyahara S, Marangell LB et al.; STEP-BD Investigators: Long-term implications of early onset in bipolar disorder: data from the first 1000 participants in the systematic treatment enhancement program for bipolar disorder (STEP-BD). Biol Psychiatry 2004; 55: 875-881.

Renk K, White R, Lauer BA et al.: Bipolar disorder in children. Psychiatry J 2014; 2014: 928685.

Seo WS, Sung HM, Sea HS et al.: Aripiprazole treatment of children and adolescents with Tourette disorder or chronic tic disorder. J Child Adolesc Psychopharmacol 2008; 18: 197-205.
Sheehan JJ, Sliwa JK, Amatniek JC et al.: Atypical antipsychotic metabolism and excretion. Curr Drug Metab 2010; 11: 516-525.

Shprecher D, Kurlan R: The management of tics. Mov Disord 2009; 24: $15-24$.

Stigler KA, Diener JT, Kohn AE et al.: Aripiprazole in pervasive developmental disorder not otherwise specified and Asperger's disorder: a 14-week, prospective, open-label study. J Child Adolesc Psychopharmacol 2009; 19: 265-274.

Stigler KA, Posey DJ, McDougle CJ: Aripiprazole for maladaptive behavior in pervasive developmental disorders. J Child Adolesc Psychopharmacol 2004; 14: 455-463.

Summary of product characteristics - aripiprazole.

Temcheff CE, Serbin LA, Martin-Storey A et al.: Childhood aggression, withdrawal and likeability, and the use of health care later: a longitudinal study. CMAJ 2011; 183: 2095-2101.

Tramontina S, Zeni CP, Ketzer CR et al.: Aripiprazole in children and adolescents with bipolar disorder comorbid with attention-deficit/ hyperactivity disorder: a pilot randomized clinical trial. J Clin Psychiatry 2009; 70: 756-764.

Van Meter AR, Moreira AL, Youngstrom EA: Meta-analysis of epidemiologic studies of pediatric bipolar disorder. J Clin Psychiatry 2011; 72: $1250-1256$.

Whitney Z, Boyda HN, Procyshyn RM et al.: Therapeutic drug levels of second generation antipsychotics in youth: a systematic review. J Child Adolesc Psychopharmacol 2015; 25: 234-245.

Woods SW, Tully EM, Walsh BC et al.: Aripiprazole in the treatment of the psychosis prodrome: an open-label pilot study. Br J Psychiatry Suppl 2007; 51: s96-s101.

Yokoi F, Gründer G, Biziere K et al.: Dopamine $\mathrm{D}_{2}$ and $\mathrm{D}_{3}$ receptor occupancy in normal humans treated with the antipsychotic drug aripiprazole (OPC 14597): a study using positron emission tomography and $\left[{ }^{11} \mathrm{C}\right]$ raclopride. Neuropsychopharmacology 2002; 27: 248-259.

Yoo HK, Joung YS, Lee JS et al.: A multicenter, randomized, double-blind, placebo-controlled study of aripiprazole in children and adolescents with Tourette's disorder. J Clin Psychiatry 2013; 74: e772-e780. 